\title{
THE BEAVER'S (CASTOR FIBER L.) APPEARANCE IN THE UZHANSKYI NATIONAL PARK AND PERSPECTIVES OF EMERGENCE OF ITS MOUNTAIN POPULATIONS IN ZAKARPATTIA
}

\author{
Nelia Koval \\ Uzhanskyi National Nature Park (Velykyi Bereznyi, Zakarpattia oblast) \\ e-mail:nelya.kowal@gmail.com
}

The Beaver's (Castor fiber L.) Appearance in the Uzhanskyi National Park And Perspectives of Emergence of its Mountain Populations in Zakarpattia. - Koval, N. - Investigations of habitats of the European beaver were carried out within the Uzhanskyi NNP. The preconditions and ways of the species dispersal are analyzed. The appearance of the European beaver in the park is considered as a consequence of reintroduction of this rodent species in neighboring Poland, namely in the mountain part of the San river's valley divided by the state border of Ukraine. Now beavers are actively occupying and adapting the territory to their own needs. Detailed investigation of signs of the species' presence showed that a persistent beaver colony exists in the park. The present status of the population is shown, as well as the perspectives of montane beaver populations' emergence in the Transcarpathian region. Due to instinctive engineering abilities to transform biotopes beavers are able to live under mountain conditions.

Key words: beaver, Castor fiber, distribution, beaver colony, Zakarpattia, Ukraine.

\begin{abstract}
Поява бобра (Castor fiber) в Ужанському національному парку і перспективи формування його гірських популяцій у Закарпатті. - Коваль, Н. - Проведено моніторингові дослідження місць поселення бобра європейського на території Ужанського НПП. Проаналізовано передумови і шляхи появи та розселення даного виду. Поява бобра європейського на території парку розглядається як наслідок процесу реінтродукції даного виду гризуна в сусідній Польщі в долині гірської ріки Сяну, поділеній державним кордоном з Україною. Тепер вони активно освоюють іiі, пристосовуючи до своїх потреб. Детальний огляд ознак перебування виду показав, що на території парку реально існує постійне боброве поселення. Показано сучасний стан його наявної популяції, як перспектива формування гірських популяцій бобра в Закарпатті. Вроджене інженерне вміння бобрів змінювати оточуюче середовище дає йому можливість проживати і в гірських умовах.

Ключові слова: бобер, Castor fiber, поширення, поселення бобрів, Закарпаття, Україна.
\end{abstract}

\section{Introduction}

The European beaver (Castor fiber L.) is one of the indigenous rodent species of the Ukrainian fauna. According to G. Panov (Панов, 2002), this rodent was formerly widespread in the country, except Crimea and the mountain regions of the Carpathians. Because of overhunting at the beginning of the $20^{\text {th }}$ century it has remained only in separate regions of the forest and forest-steppe zones. In both Zakarpattia and Prykarpattia, as Turianin stated, the European beaver was common in fens and marshes along the edge of rivers (Турянин, 1976). In the result of overhunting for its fur and reducing of food supply (deforestation of poplar, aspen, willow, alder and linden woods) at the end of the $17^{\text {th }}$ century the beaver became rare, and in the first quarter of the $18^{\text {th }}$ century extirpated.

The reintroduction of the species in the neighboring countries and its further natural expansion to the territory of Ukraine were the preconditions of the beaver's appearance in the region of the Ukrainian Carpathians. To Zakarpattia beavers immigrated mainly from Hungary and Slovakia, while to the Beskids they entered from Poland. In Zakarpattia the beaver was observed first at the beginning of the $21^{\text {st }}$ century in the basin of the Uzh river. The first colony was found in 2003. Individuals that colonized the lower course of the river apparently immigrated from Slovakia, while the 
basin of the river's upstream portion was settled by animals which emigrated from Poland. In the same time, the Tysa river was colonized by beavers entered, most likely, from Hungary (Башта, Потіш, 2012).

As Bashta and Potish state (ibid.), during the last decade the beavers rapidly spread along the Latorytsia, Borzhava and Tysa rivers. The temp of resettlement in the other side of the Carpathians is rather slower and the beavers entered into the mountains to a lesser extent. However, considerable expansion of the species in the foothill and mountain portions of the Uzh and Latorytsia rivers in Zakarpattia, and mountain rivers of the Beskids and the Gorgany may be significantly limited by a number of barriers of various origin, such as unfavorable physical conditions of water streams, considerable slope causing high speed of water flow, limited food supply etc. Therefore, within mountain and foothill regions the management of beaver populations should be carried out based on basin approaches.

The main goal of the present work is to show the mechanisms of emergence of a mountain beaver population, also the difficulties and prospects of its development in light of data on a local European beaver population existing under the conditions of the Uzhanskyi National Nature Park.

\section{Material and methods}

The present work is based on results of the author's permanent monitoring research conducted during the last six years on territories periodically (vicinities of Lubnia village) and constantly (Uzhok mountain pass) inhabited by beavers. The objects of our research are the beaver habitats and also the individuals.

Censuses were held in spring and autumn. Field studies included detailed description and count of all revealed signs of the species' activity. During investigations of beaver settlements we recorded all signs of the animal's activity related to its presence on the territory (tab. 1). In addition, the analysis was complemented by data from available publications on the fauna of Zakarpattia and from publications of polish researchers as well.

\section{Physiographic features of the territory}

The Uzhanskyi National Nature Park is situated in the western part of Zakarpattia in the basin of the Uzh river. The territory of the Uzhanskyi NNP (fig. 1) is in the zone of low mountain ridges of the Eastern Beskids with average height of $1000 \mathrm{~m}$ asl and is intensely divided by a net of mountain streams among which there are 52 larger ones. Their content of water varies during the year according to the amount of precipitations.

Due to considerable amount of precipitations and fragmented terrain the park's territory is characterized by a branched net of water streams. The main water artery is the Uzh river which originates eastward from the Uzhok mountain pass, the contact zone of watersheds of the Black (the Dniester river) and the Baltic sea (the San river). Because of significant decline in forested areas during the agricultural period there is a violation in the hydrological regime of the Uzh river periodically causing floods. The park is situated in the mountains, the orographic effect of which significantly affects the climate. In winter in the park's territory falls over $120 \mathrm{~mm}$ of solid precipitation. Therefore, sometimes avalanches occur in highlands.

Frequent thunderstorms in summer and considerable accumulation of snow in winter cause 5-7 floods per year with significant destruction of river banks (Стойко et al., 2008). It develops adverse conditions for the beavers which life and activity are connected with the water all year round. In the same time, it leads to the development of floodplain forests along mountain rivers and streams dominated by willow, alder and aspen with hydrophilic vegetation in the undercover. Such food supply, apparently, attracts the beaver. Among the main preconditions for the beaver's colonization are the presence of water and food, especially willow. As polish colleagues state (Derwich, Mroz, 2009), even a small stream with few willows is enough for the beaver to form a settlement. The ability of beavers to build dams helps to accumulate water in ponds and contributes the development of riparian vegetation as well. 
Table 1. Signs of the beaver's life activities revealed in the territory of the Uzhanskyi NNP

Таблиця 1. Виявлені ознаки життєдіяльності бобрів на території Ужанського НПП

\begin{tabular}{llll}
\hline Signs of the beaver's activity & Lubnia village & Uzhok village & Sources \\
\hline Gnawed bark on trees & present & present & personal observations \\
Gnaw marks on fallen trees & present & present & personal observations \\
Food caches & present & present & personal observations \\
Canals & absent & present & personal observations \\
Trails & absent & present & personal observations \\
Burrows & absent & present & personal observations \\
Lodges & literature sources & present & personal observations \\
Dams & absent & present & personal observations \\
Osteological material & absent & 1 skull & found personally \\
Visual observations & 1 individual & 6 individuals & observations by local residents \\
\hline
\end{tabular}

\section{The European beaver's expansion in the mountain part of Zakarpattia}

In Zakarpattia, the expansion of the beaver has mainly canalized character, i.e. it takes place along the main rivers and their tributaries. Geographic barriers such as mountain ridges often limit the ability of individuals to migrate into basins of neighboring river systems. In our case the appearance of the beaver from the northeastern macroslope is an exception, which is most likely due to significant increase in density of its population in the Beskids. This caused the beaver's migration not only along the ridges in the Beskids, but also through them to the side of Zakarpattia. By 2012, the beaver was known from more than 60 localities in Zakarpattia, among which there were about 50 settlements (Башта, Потіш, 2012).

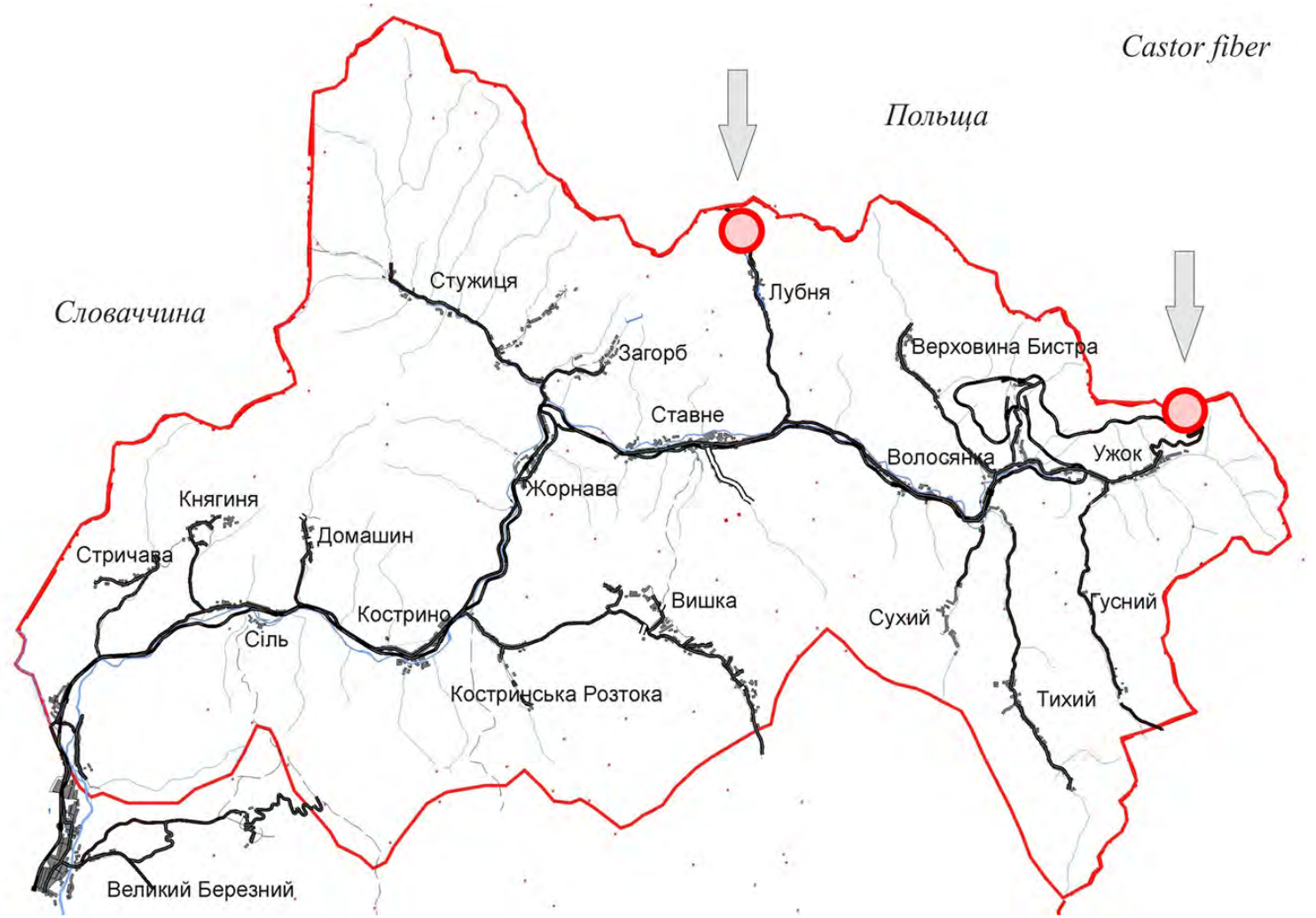

Fig. 1. Sketch map of the Velykyi Bereznyi raion with indications of records of Castor fiber in the Uzhanskyi NNP. Рис. 1. Схема Великоберезнянського району з позначенням місць знахідок бобра в Ужанському НПП. 


\section{The emergence of the beaver population in the Uzhanskyi park}

The species is not mentioned in the first general fauna checklists of the Uzhanskyi NNP. The beaver's very first attempt to settle down within the park's territory was recorded in 2003 near Lubnia village in the mountain river of the same name, where a beaver settlement consisting of 3 lodges was found. The animals probably came from the territory of Poland. Historically the beaver's appearance in the Lubnianka river coincides with its return to Zakarpattia. However, in 2005, according to data reported by the staff of the Uzhanskyi NNP no individuals were observed in the settlement (Башта, Потіш, 2007).

Signs of the beaver's activity within the park were newly recorded in May 2009. A small river running through Lubnia village and having overgrown banks and rapid flow, and which in some places does not freeze even in extreme cold, obviously, attracted the rodent. Although the animal was not observed, signs of its activity were photographed: on the river bank there was a gnawed willow with diameter of 15-20 cm, a bunch of randomly dumped branches which, apparently, was an attempt to build a lodge. The beaver's presence here has been noticed for a while, but heavy rains caused a flood which destroyed all its further attempts to create a settlement.

The beaver appeared again in these areas in summer 2010: on $15^{\text {th }}$ of July the villagers observed an individual periodically showing up in the Lubnianka river near the village, in the Karier tract (ca. $450 \mathrm{~m}$ asl), but later the animal disappeared. This locality is not far from the polish state border.

In the mountain portion of the San river's basin the first beaver family was recorded in autumn 1993. Most likely the local population has been formed by this family. In 1999, the territory (over 1500 ha) was passed to the Bieszczady National Park. On the received lands the park implements a program on wetland protection. Habitats proved to be favorable for the beavers were occupied and the animals arranged their own buildings on the territory. Transformations of these areas implemented by the beavers significantly affected the rate of renaturalization of the valley's depleted ecosystems. This process was helped by the development of the European beaver population. The gradual increase in the number of settlements and the expansion of occupied territories caused the migration of beavers into river valleys located on the Ukrainian side of the border (Derwich, Mroz, 2009).

Obviously, all the beavers that appeared in the Uzhanskyi park came from Poland. In the Bieszczady mountains, namely in the depleted mountain valley of the San river, due to implementation of beaver restoration programs in 1995-2008 and further natural expansion, the species' population number has reached more than 180 individuals in 90 settlements. The increase in the number of population was facilitated by the lack of significant human impact. Since 1998, migration of female beavers to Ukraine has been periodically observed (Derwich, Mroz, 2009). Obviously, the beaver's appearance in the Uzhanskyi park is a result of its natural expansion.

In vicinities of Uzhok village (870 m asl) signs of the beaver's activities were first observed in 2011. The animals occupied floodplain meadows in the valley of the San river in its mountain portion which are crossed by the Polish-Ukrainian state border. Though for the beavers there are no state borders - we can state it according to numerous trails on both sides of the border. Sufficient riparian vegetation and the presence of deep and not rapid streams with silty bottom turned out favorable to settle down in these territories.

Especially vigorous activity of beavers to create a settlement became prominent in early spring of 2013 in two small mountain streams that flow from Beskidets Mountain and fall into the San river. The beavers built dams on these streams and, as a result, two ponds were formed with hydrophilic vegetation as well as large areas of floodplain meadows (fig. 2).

\section{Occupied habitats and history of colonization of the species}

As of today, the beaver colony occupies an area of about 2 ha (fig. 3), covered mainly by floodplain meadows intensively overgrowing by willow and alder, and partly by a mature beech-fir forest. We have found two beaver lodges situated opposite one another on the banks of the widest stream (width about $5 \mathrm{~m}$ ) with entrances located under the water surface. 


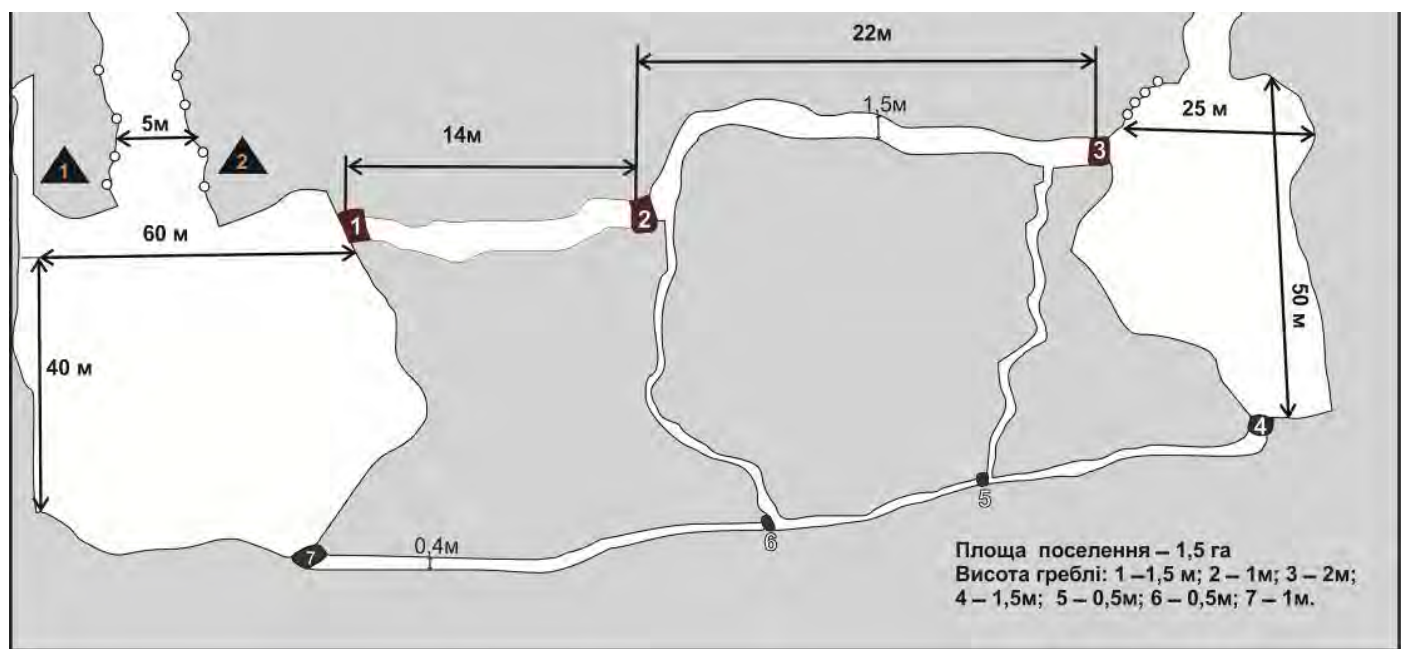

Fig. 2. Sketch map of the studied beaver settlement.

Рис. 2. Картосхема досліджуваного бобрового поселення.

Legend: $\mathbf{\Delta}$ - lodge, $\mathbf{\Lambda}$ - dam, $\mathrm{O}$ - burrow, $\square$ - water body, $\square$ - floodplain meadow.

In the banks of streams, beaver canals and ponds there are numerous burrows, some of which have exits on the meadows and are connected by a system of underground tunnels.

There are 7 beaver dams in the territory (fig. 4) with height of $0.5-2 \mathrm{~m}$, also two ponds with dens and rich aquatic and riparian vegetation. The beaver ponds are connected by canals which width is about $0.4-1.5 \mathrm{~m}$. These canals even during intense heat are filled with water. On the banks of water bodies there was revealed a considerable number of gnaw marks on trunks of willow, alder and even beech and fir trees (thickness up to $1 \mathrm{~m}$ ).

According to reports, at least five individuals were witnessed in the colony. In addition, one beaver skull was found and identified as a two years old male's one. Based on all collected data we can assume the permanent presence of a beaver family consisting of at least 4-6 individuals.

In autumn 2015 we did not find new beaver lodges and the two formerly built lodges did not increased in size. As Stopka stated (Stopka, 2011), in neighboring Polish colonies, beaver lodges built for safety were not detected, however a significant number of tunnel systems and burrows dug in steep banks were revealed. Such signs of presence of this rodent are common in the area of the Uzhok mountain pass as well. During observations provided at the end of October 2015 we have noticed that beaver canals became significantly wider and deeper, and the surface of water bodies increased too. The considerable number of gnawing marks and freshly cut trees proved that the beavers were preparing for winter accumulating food supply and they were not going to leave the territory. All these facts allow to suggest that the beaver family which lives in vicinities of Uzhok village is part of the population inhabiting in the valley of the San river - geographically it is one region, so the state border is only for men but not for the beavers. Floodplain meadows with a large number of beaver canals in the mountain portion of the San river's valley are the territory of the beavers, a colony of which inhabits directly in the border zone.

The beaver has not became a common species in the Uzhanskyi park yet. To meet this rodent causes people to wonder and even to admire. Since 2003, the species has been obstinately occupied the territory and we expect to include the beaver into the park's fauna checklist. This confirms again the opinion of I. Zagorodniuk (Загороднюк, 2006) that in case of natural invasions almost all species became part of the local fauna. This process often leads to emergence of synanthropic populations existing under considerably transformed by human conditions and which are often obligate synanthropes. Unlike introductions, reintroductions enable communities and ecosystems to regain some features they have lost before, which means that reintroductions can be considered as a positive phenomenon. We hope that the same process is happening in our case as well. 

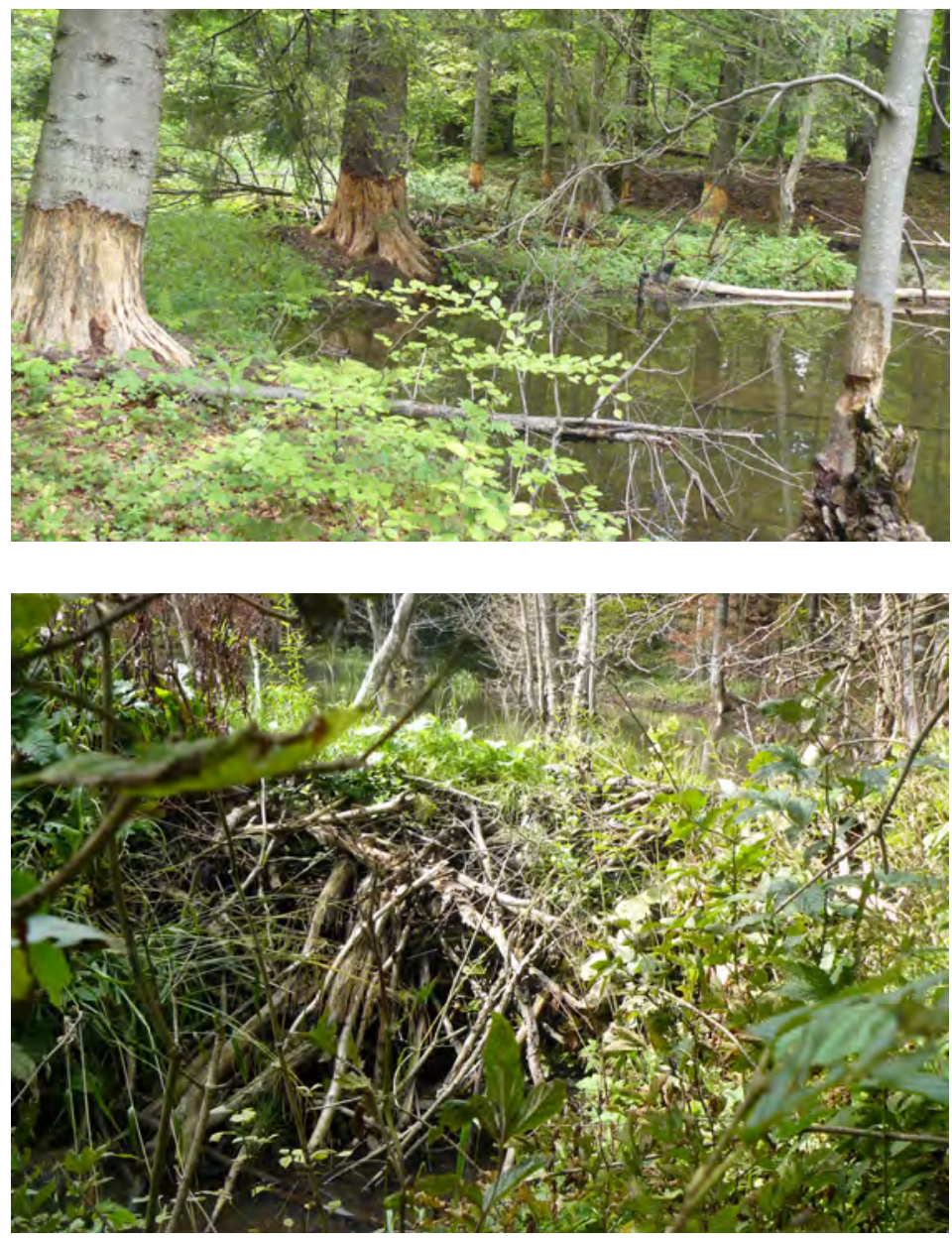

Fig 3. A beaver settlement in vicinities of Uzhok village (August 2013).

Рис. 3. Боброве поселення в окол. с. Ужок (серпень 2013 р.)

Fig 4. The highest beaver dam $(2.5 \mathrm{~m})$ in vicinities of Uzhok village (August 2013).

Рис. 4. Найвища дамба (2,5 м), збудована бобрами в окол. с. Ужок (серпень, 2013).

Besides, lands occupied by beavers are unsuitable for cultivation because they are regularly flooded, overgrown by willow and alder, which make them, however, suitable for beavers. In addition, the state border prevents people's free access to the territory. Thus, low anthropogenic pressure also ensures that that the rodent does not leave the territory.

The beaver is probably the only animal species of the temperate climate zone that shows ability to transform the habitat intensively and purposefully in order to adapt it to its claims related with providing sufficient amount of food and hiding place. The beaver's appearance in areas transformed in the result of anthropogenic impact led to increase the landscape diversity and to changes in the flora composition within their habitats (Башта, Потіш, 2012). The species' natural engineering abilities helped to occupy and transform habitats under severe physiographic conditions in the mountain part of Zakarpattia. Therefore, we expect the emergence of a stable mountain population of the European beaver in the territory.

\section{Conclusions}

In the result of long-term monitoring studies and analysis of data from other researchers we could determine:

1) The main preconditions of the beaver's appearance in the Uzhanskyi NNP were the following: presence of a stable neighboring beaver colony in the upstream portion of the San river within the territory of the Bieszczady park (Poland), favorable conditions in the area of mountain rivers and streams, sufficient food supply, vegetation and low anthropogenic pressure. 
2) As of autumn 2014, in vicinities of Uzhok village has been formed a small, yet unstable local beaver population.

3) The formation of a settlement in vicinities of Lubnia village is affected by unfavorable environmental factors such as frequent seasonal floods and rapid river flow, which during heavy thunderstorms is extremely turbulent and can wash away the riparian vegetation, erode the banks and destroy buildings made by the rodent.

4) The beaver's appearance in the territory of the Uzhanskyi NNP is a striking example of the emergence of a mountain beaver population in Zakarpattia.

5) Beaver settlements in the Uzhanskyi NNP prove that even under mountain conditions innate instincts help these animals not only survive these challenging conditions, but also to modify them to their own needs.

In the present paper we showed the ways of the settlement and expansion of the species and gave detailed description and estimation of their habitats, in particular how beavers create conditions for their own existence under mountain conditions at such altitudes ( $870 \mathrm{~m}$ asl). We also showed the information on the current state of the European beaver population which exists in the studied territory, and how this species is able to create for itself optimal living conditions.

\section{Acknowledgement}

The author would like to thank to I. Zagorodniuk (National Museum of Natural History, NAS of Ukraine) and Z. Barkasi (National Museum of Natural History, NAS of Ukraine) for their support and aid during preparation and writing of this article.

\section{Лiтература}

Башта, А.-Т. В., Потіш, Л. А. Ссавці Закарпатської області. - Львів, 2007. - 260 с. [Bashta, A.-T., Potish, L. Mammals of the Transcarpathian Region (Ukraine). — Lviv, 2007. — 260 c. (in Ukr.).]

Башта, А.-Т. В., Потіш, Л. А. Експансія бобра європейського Castor fiber L. в регіоні Українських Карпат // Науковий вісник Ужгородського ун-ту. Сер. Біол. - 2012. — Вип. 33. — С. 144-153.

[Bashta, A.-T., Potish, L. Expansion of European beaver Castor fiber L. in the Ukrainian Carpathians area // Scientific Bulletin of the Uzhgorod University. Series Biology. — 2012. — Vol. 33. — P. 144-153. (in Ukr.).]

Загороднюк, I. В. Адвентивна теріофауна України і значення інвазій в історичних змінах фауни та угрупувань // Фауна в антропогенному середовищі. - Луганськ, 2006. - С. 18-47. — (Праці Теріологічної школи; Вип. 8).

[Zagorodniuk, I. Adventive mammal fauna of Ukraine and a significance of invasions in historical changes of fauna and communities // Zagorodniuk I. (ed.). Fauna in Anthropogenic Environments. — Luhansk, 2006. — P. 18-47. — (Series: Proceedings of the Theriological School; Vol. 8).]

Панов, Г. Динаміка ареалів та чисельності напівводяних хутрових звірів в Україні у другій половині ХХ століття // Вісник Львівського університету. Серія біологічна. — 2002. — Вип. 30. - С. 119-132.

[Panov, G. Dynamics of ranges and of abundances of semi-water fur-bearing mammals in Ukraine during second part of the XX century // Visnyk of Lviv University. Biology Series. — 2002. — Is. 30. — P. 119-132. (in Ukr.).]

Стойко, С. М., Гадач, Е., Тасєнкевич, Л. О. та ін. Ужанський національний природний парк. Поліфункціональне значення.- Львів, 2008. - 306 с.

[Stoyko, S., Gadach, E., Tasenkevich, L. U. et al. Uzhanskyi National Natural Park. Multifunctional Significance. - Lviv, 2008. - 306 p. (in Ukr.).]

Турянин, I. I. Хутрово-промислові звірі та мисливські птахи Карпат. - Ужгород : Карпати, 1975. — 176 с. [Turianyn, I. Fur-Industrial Mammals and Hunting Birds Carpathians. — Uzhgorod: Carpathians, 1975. — 176 p. (in Ukr.).]

Derwich, A., Mróz, I. Rozwoj populacji bobra europejskiego Castor fiber nad gornym Sanem (Bieszczadzki Park Narodowy) w latach 1993-2009 // Roczniki Bieszczadzkie. - 2009. — Tom 17. — S. 283-306.

Stopka, $R$. Geomorfologiczne skutki dzialalnociści bobra europejskiego Castor fiber w doline gornego Sanu // Roczniki Bieszczadzkie. — 2011. — Tom 19. — S. 319-334. 